УДК 658:338.2

DOI: https://doi.org/10.37320/2415-3583/12.20

Клименко Л.В.

кандидат економічних наук,

Уманський національний університет садівництва ORCID: http://orcid.org/0000-0002-2126-5126

Загороднюк О.В.

кандидат економічних наук,

Уманський національний університет садівництва ORCID: http://orcid.org/0000-0002-8297-2123

Халахур Ю.Л.

кандидат економічних наук,

Уманський національний університет садівництва ORCID: http://orcid.org/0000-0002-3474-8418

\title{
ДІАЛЕКТИКА ПОНЯТТЯ «ЕКОНОМІЧНИЙ РОЗВИТОК ПІДПРИСМСТВ» В СИСТЕМІ МЕНЕДЖМЕНТУ
}

У статті узагальнено наукові діалектичні поняття економічного розвитку підприємств, які передбачають реорганізацію та переорієнтацію соціально-економічної системи. Відображено взаємозалежності структурних складових частин економічного розвитку підприсмства. Аналізуючи масштабність сучасних структурних зрушень в економіці України, ми навели класифікачію видів розвитку суб'єктів господарювання на основі змістових критеріїв. Обтрунтовано необхідність впровадження сучасних методів прийняття управлінських рішень, спрямованих на конкретизацію пріоритетів, нарощування ресурсного забезпечення та розроблення дієвих стратегій розвитку. Доведено, щцо організачійно-економічними важелями збалансованого стабільного розвитку вітчизняних підприємств є впровадження конкурентоздатних високотехнологічних інноваційних процесів виробництва за умов інтеграційних зусиль організаџій та підприємств зовнішнього й внутрішнього середовища.

Ключові слова: економічний розвиток, управління, адміністративний менеджмент, стратегї розвитку, конкурентоздатність.

Постановка проблеми. Ефективна система менеджменту на підприємствах, без сумніву, була, $є$ й надалі залишатиметься базовою рушійною силою соціально-економічного розвитку, тому проблематика наукових досліджень щодо питань економічного розвитку господарюючих суб'єктів та ефективних методів управління ними ніколи не втратить своєї актуальності. Чимало зарубіжних та вітчизняних наукових діячів присвятили свої роботи вивченню феномена економічного розвитку й розробили дієві стратегічні рішення та моделі. Однак за умов посилення інтеграційних та глобалізаційних процесів розвиток національної економіки характеризується не лише високою швидкістю змін, але й нестабільністю та невизначеністю в системі менеджменту. Отже, адміністративний менеджмент господарюючих суб'єктів потребує сучасних методів прийняття управлінських рішень та стратегій, спрямованих на забезпечення безперервного процесу економічного розвитку підприємств з урахуванням раціонального використання ресурсів, підвищення прибутковості виробництва, зростання якості продукції та її конкурентоспроможності, а також задоволення соціальних потреб працівників.

Аналіз останніх досліджень і публікацій. Дослідження поняття «економічний розвиток» у категоріальному апараті наукових теорії знайшло своє відображення у працях вітчизняних та зарубіжних дослідників. Перші наукові трактати цієї проблематики були відображені у працях Ф. Кене, Ф. Рамсея [1], Д. Рікардо [2], К. Маркса [3], А. Сміта [4, с. 21-22].

Наявність значних економічних прогалин у функціонуванні економіки України, дискусійних поглядів щодо ії розвитку, багатовекторних стратегій і методів економічного зростання формують потребу не лише екскурсу в надбання світової економічної думки, але й певного узагальнення сучасних теоретичних і методичних принципів розвитку та управління.

Особливості сучасного розвитку підприємств за багатовимірних параметрів i напрямів функціонування економіки відображено у працях Т.Б. Надтоки, Г.А. Какуніна [7], Ю.А. Плугіна [8], Р.О. Побережного, Н.М. Побережної [9], О.Є. Кузьміна, А.М. Дідика [13] та інших науковців.

3 огляду на значні наукові досягнення в галузі обгрунтування теоретичних основ розвитку господарюючих суб'єктів та постійні зміни у формах власності, методах та принципах державного регулювання, посилення міжнародної конкуренції та активізації інтеграційних і глобалізаційних процесів, а також за умов системних кризових явищ дослідження розвитку підприємств потребує подальших наукових досліджень.

Мета статті полягає в узагальненні категоріального апарату «економічний розвиток підприємства», обгрунтуванні системи управління суб'єктами господарювання за сучасних умов структурних трансформацій.

Теоретико-методологічною основою дослідження $\epsilon$ загальнонаукові та спеціальні методи наукового пізнання (методи наукової дедукції та індукції, порівняння та систематизації, синтезу).

Виклад основного матеріалу. В економічному енциклопедичному словнику зазначено, що економічний розвиток - це незворотні, спрямовані, закономірні зміни економічної системи в довготерміновому 
періоді, що відбуваються під впливом економічних суперечностей, потреб та інтересів, зумовленість яких характеризується дією основних законів діалектики, що не виходять за межі глибинної внутрішньої сутності такої системи [4].

К. Маркс у I томі «Капіталу» започаткував діалектику економічного розвитку та зростання. Він стверджував, що якісні зміни та зрушення у продуктивних силах і виробничих відносинах називаються розвитком та відкривають простір для кількісних змін, тобто стають потужним локомотивом зростання. За умов інтенсивного впровадження нової техніки та інноваційних технологій зростання стає якісним і набуває рис розвитку [3].

Наукові дослідження Р.А. Коненкова обгрунтовують різнополярність економічного росту та структурних зрушень у системі економічного розвитку. Він стверджує, що економічний ріст - це зовнішній прояв сутності економічного розвитку, а структурні зрушення це внутрішній ресурс (рис. 1) [6].

Структурною складовою частиною досліджень категорії «економічний розвиток» $є$ суб'єкт господарювання. Підвищений інтерес науковців до феномена економічного розвитку саме підприємств породжує значну кількість діалектичних підходів до трактування цього поняття (табл. 1).

Систематизація наявних дефініцій поняття «економічний розвиток підприємства» в науковій літературі дав змогу виокремити два діалектичних аспекти його трактування, а саме у вузькому та широкому розуміннях

У вузькому розумінні розвиток суб'єкта господарювання розглядають як стан чи результат зміни діяльності (складу, властивостей) підприємства,

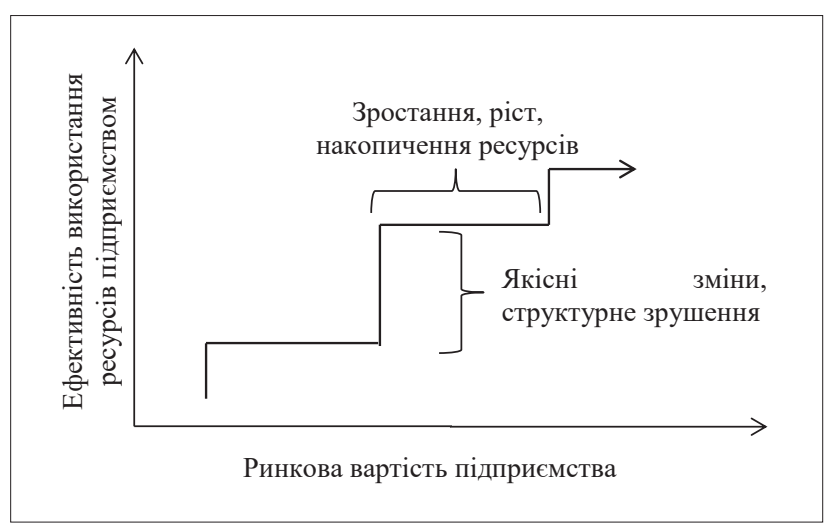

\section{Рисунок 1 - Траєкторія формування взаємозалежності структурних складових частин економічного розвитку підприємств}

Джерело: узагальнено авторами на основі джерел [3; 6]

його переходу в інший кількісний та якісний рівень під впливом факторів внутрішнього та зовнішнього середовища $[7 ; 8 ; 13 ; 14]$.

У широкому розумінні розвиток підприємства трактується як незворотній, спрямований, закономірний процес, який є безперервною та послідовною зміною (сукупність змін) результатів чи станів підприємства в часі та просторі на кількісно та якісно інший за попередній стан під впливом факторів внутрішнього та зовнішнього середовища $[5 ; 9 ; 10 ; 11 ; 12]$.

Економічний розвиток підприємств залежить від наявності традиційних факторі виробництва, зокрема землі, капіталу, праці, менеджменту, технологій. Водночас не варто відкидати впливи факторів другого

Таблиця 1 - Діалектика поняття «економічний розвиток суб'скта господарювання»

\begin{tabular}{|c|c|}
\hline Автор & Визначення \\
\hline $\begin{array}{l}\text { Т.Б. Надтока, } \\
\text { Г.А. Какуніна [7] }\end{array}$ & $\begin{array}{l}\text { Процес сукупних змін у соціально-економічній системі підприємства, спрямований на його перехід у } \\
\text { новий якісно-кількісний стан у часі під впливом факторів внутрішнього та зовнішнього середовища, } \\
\text { причому за напрямом він може бути як позитивним, так і негативним. }\end{array}$ \\
\hline $\begin{array}{l}\text { Ю.А. Плугіна } \\
{[8, \text { с. } 326]}\end{array}$ & $\begin{array}{l}\text { Якісні перетворення в діяльності підприємств за рахунок змін кількісних і структурних характеристик } \\
\text { техніко-технологічних, організаційно-комунікаційних, фінансово-економічних ресурсів на основі } \\
\text { ефективного використання інтелектуально-кадрових ресурсів та інформаційних технологій. }\end{array}$ \\
\hline $\begin{array}{l}\text { Р.О. Побережний, } \\
\text { Н.М. Побережна } \\
{[9, \text { с. } 232]}\end{array}$ & $\begin{array}{l}\text { Спрямована зміна якісного стану організації, іiі структури, складу або властивостей, кількісних } \\
\text { чи якісних зрушень серед елементів організації. При цьому розвитку організації притаманні ті ж } \\
\text { властивості, що й «філософському розвитку», тобто циклічність і спіральність. }\end{array}$ \\
\hline $\begin{array}{l}\text { О.В. Раєвнєва, } \\
\text { І.В. Аксьонова, } \\
\text { Г.І. Свидло [10] }\end{array}$ & $\begin{array}{l}\text { Унікальний процес трансформації відкритої системи в просторі та часі, який характеризується } \\
\text { перманентною зміною глобальних цілей його існування, шляхом формування нової дисипативної } \\
\text { структури, а також переводом його в новий атрактор (одна } 3 \text { альтернативних траєкторій розвитку } \\
\text { підприємства) функціонування. }\end{array}$ \\
\hline $\begin{array}{l}\text { А.В. Дакус, } \\
\text { Н.О. Сімченко [11] }\end{array}$ & $\begin{array}{l}\text { Незворотні, керовані, вимірювальні, цілеспрямовані, закономірні кількісно-якісні та сутнісні } \\
\text { зміни економічної системи в довгостроковому періоді, що відбуваються під впливом економічних } \\
\text { суперечностей, потреб та інтересів, зумовленість яких характеризується дією основних законів } \\
\text { діалектики, що не виходять за межі глибинної внутрішньої сутності такої системи, для забезпечення } \\
\text { найбільш оптимального та ефективного функціонування підприємства. }\end{array}$ \\
\hline $\begin{array}{l}\text { В.Ф. Кифяк } \\
{[12, \text { с. } 193]}\end{array}$ & $\begin{array}{l}\text { Динамічна система взаємодіючих підсистем, передумов, факторів і принципів, які формують вектор } \\
\text { кількісних та якісних змін функціонування підприємства, спрямованих на досягнення пріоритетів. }\end{array}$ \\
\hline $\begin{array}{l}\text { О.Є. Кузьмін, } \\
\text { А.М. Дідик }[13, \text { с. 7] }\end{array}$ & $\begin{array}{l}\text { Розвиток кожної організації, що має циклічний характер, тобто проходить через певні стадії } \\
\text { життєвого циклу, що визначають особливості виробничо-господарської, інвестиційної, фінансової } \\
\text { та інших видів діяльності. }\end{array}$ \\
\hline $\begin{array}{l}\text { М.Н. Нечепуренко } \\
{[14, \text { с. 23] }}\end{array}$ & $\begin{array}{l}\text { Процес оновлення виробничих процесів або бізнес-процесів, що забезпечує якісно новий рівень } \\
\text { функціонування підприємства. }\end{array}$ \\
\hline
\end{tabular}

Джерело: сформовано авторами на основі джерел [7-14] 
порядку, а саме форм і типів власності, політичних та економічних інституцій, релігійних та культурних особливостей $[15$, с. 217]. Вагоме значення мають також рівень суспільного поділу й кооперації праці та виробництва, розвиток відповідних економічних форм, у яких реалізуються виробничо-господарські процеси.

Контент-аналіз сформованих дефініцій поняття «економічний розвиток підприємства» дає змогу відобразити багатоаспектність цього явища, ідентифікуючи видову структуру за факторними та змістовими критеріями (рис. 2).

Характерними особливостями розвитку сучасної світової економіки є системні процеси інтернаціоналізації, глобалізації, регіоналізації та інтеграції. Інтеграційні процеси, охопивши всі сфери життя, стрімко трансформують світову економіку з пози- ції нівелювання внутрішніх бар'єрів державних кордонів, а разом із позитивними аспектами розвитку національної економіки зумовлюють нагромадження деструктивних тенденцій у соціально-економічному розвитку. Кожне з підприємств по-різному реагує на структурні зрушення в економіці України. Однак більшість підприємців, не маючи достатнього досвіду функціонування у глобальному середовищі, вдається до значних дисфункцій у господарській діяльності, використовуючи схему менеджменту «проб і помилок».

Управлінські помилки в розвитку національної економіки досить часто зумовлюють загострення соціальних проблем у суспільстві, а несвоєчасність конструктивних рішень у ринковому середовищі провокує зростання рівня корупції, лобіювання певних рішень

і законів, тіньової економіки та зловживання монопольним положенням.

Зазвичай реалізація стратегічних рішень розвитку підприємств потребує впровадження сучасних методів прийняття управлінських рішень на основі наявного внутрішнього потенціалу та передбачає оцінювання зовнішніх умов функціонування (рис. 3).

Серед організаційно-економічних важелів зовнішнього оточення п підприємницької діяльності виокремлюють постачальників, споживачів, конкурентів, оцінюють наявне політично-правове, науковотехнічне, економічне, соціокультурне, природне середовище та міжнародне оточення. Відповідно, найважливішими завданнями менеджменту $\epsilon$ впровадження сучасних методів прийняття управлінських рішень щодо забезпечення своєчасних адаптаційних умов відповідно до мінливого зовнішнього середовища.

Серед внутрішніх важелів економічного розвитку підприсмств, які потребують систематичного управлінського контролю, виокремлюють ресурсний потенціал, залучення енергозберігаючих технологій виробництва, вмотивованість трудових ресурсів, інноваційно-інвестиційну діяльність тощо.

На міжнародному ринку стрімкий розвиток конкурентоспроможних і високотехнологічних галузей забезпечується зазвичай збільшенням наукоємності цієї галузі та

Джерело: узагальнено авторами на основі джерел [16; 17$]$ 


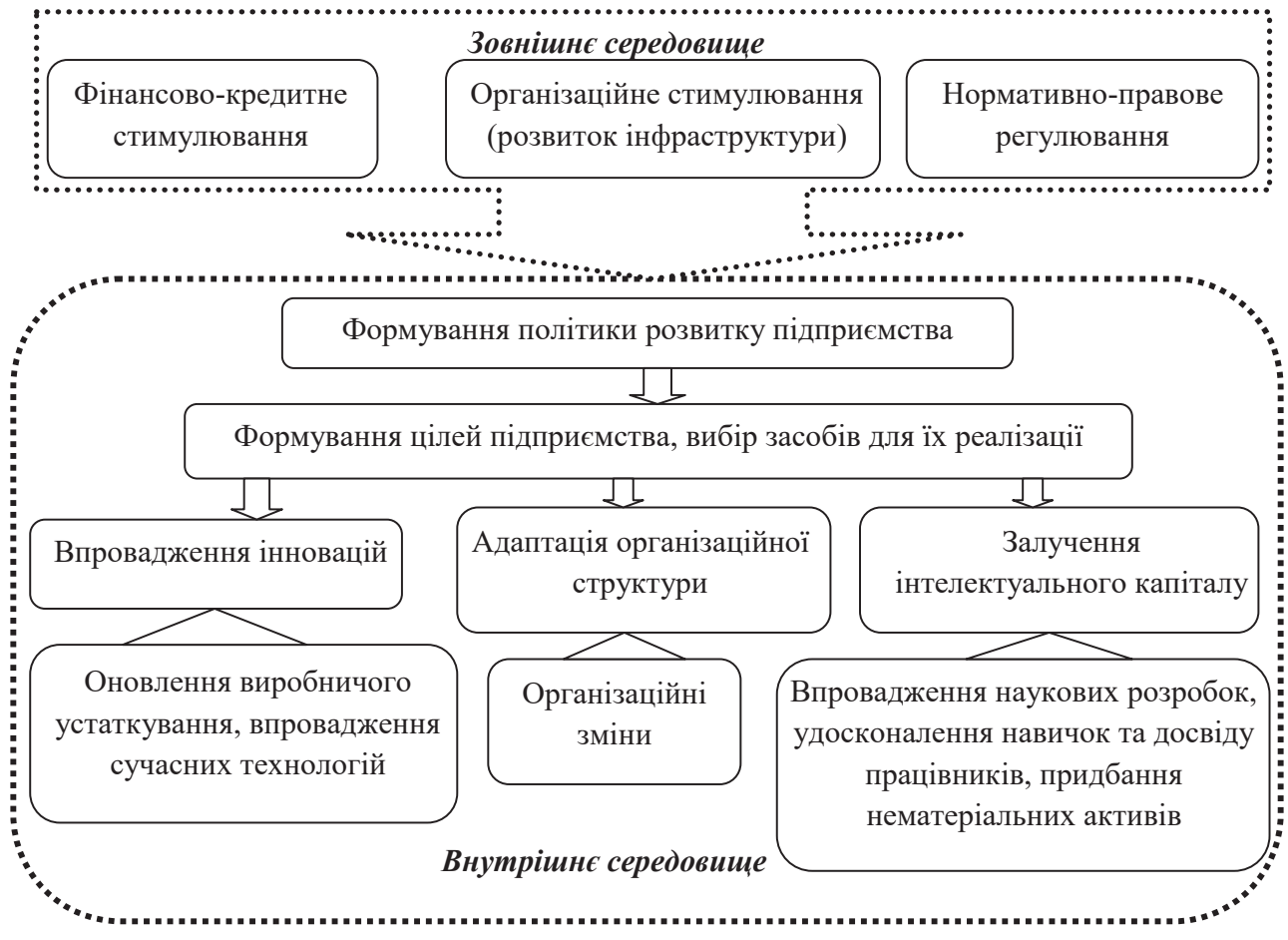

Рисунок 3 - Організаційно-економічні важелі економічного розвитку підприємств

Джерело: авторська розробка

максимальним використанням прав інтелектуальної власності, які у сучасних умовах виробництва $\epsilon$ одними 3 найбільш вартісних складових частин суспільного продукту.

На нашу думку, множинність стратегічних рішень щодо розвитку підприємств в умовах посиленого глобального ринкового вектору доцільно сформувати за такими напрямами:

1) диверсифікація виробництва конкурентоздатних видів продукції для забезпечення стійкості господарюючого суб'єкта за умов певного маневрування ресурсами;

2)запровадження енергозберігаючих екологічно чистих технологій виробництва якісної продукції, яка користуватиметься високим попитом на внутрішньому та зовнішньому ринках;

3) розширення ринкового сегменту 3 поступовим виходом на зовнішні ринки з огляду на різноманітність смаків споживачів та використання активної рекламної кампанії;

4)горизонтальна та вертикальна інтеграція, спрямована на економічно обгрунтовану співпрацю з конку- рентами, стейкхолдерами, постачальниками сировини та послуг, фінансовими структурами тощо.

Висновки. Отже, економічний розвиток підприємства - це незворотні, керовані, цілеспрямовані, закономірні кількісно-якісні та сутнісні зміни економічної системи суб'єкта господарювання, а також оптимальних результатів чи станів ефективного функціонування господарської діяльності в довгостроковому періоді, які зумовлені впливом економічних суперечностей, потреб та інтересів на основі законів діалектики.

Сучасна національна економіка в умовах глобалізаційних змін потребує структурних трансформацій та реформ, впровадження сучасних методів прийняття управлінських рішень які б забезпечили вітчизняним товаровиробникам можливість стати конкурентними гравцями на світовому ринку. Векторна спрямованість стратегій та оптимізаційних моделей розвитку підприємств має передбачати диверсифікацію, розвиток ринкової інфраструктури, виробництво конкурентоздатної екологічно чистої продукції з використанням енергозберігаючих технологій інноваційного характеру.

\section{Список використаних джерел:}

1. Ramsey F. Mathematical Theory of saving. Economic Journal. 1928. Vol. 38. P. 543-559.

2. Рикардо Д. Сочинения в пяти томах. Москва : Госполитиздат, 1955. Т. 1 : Начало экономии и налогового обложения. 360 с.

3. Маркс К. Капитал. Т. 1. Москва, 1960. 907 с.

4. Смит А. Исследование о природе и причинах богатства народов. Москва : Наука, 1993. Кн. I-III. 148 с.

5. Економічний енциклопедичний словник : у 2 т. Т. 1 / за ред. С.В. Мочерного. Львів : Світ, 2005. 616 с.

6. Коненков Р.А. Диагностика качества экономического роста и развития предприятия. Волгоград : Волгоградская правда, 1988. $112 \mathrm{c}$.

7. Надтока Т.Б., Какуніна Г.А. Соціальний розвиток промислового підприємства та механізми його управління. Управленческие технологии в решении современных проблем развития соииально-экономических систем : монография / за заг. ред. О.В. Мартякової. Донецьк : ДВНЗ «ДонНТУ», 2011. С. 564-569. 
8. Плугіна Ю.А. Розвиток персоналу підприємства: підходи, сутність, моделі. Вісник економіки транспорту і промисловості. 2013. Вип. 42. С. 323-327.

9. Побережний Р.О., Побережна Н.М. Методологічні аспекти сучасних підходів до сутності розвитку підприємства в умовах мінливого зовнішнього середовища. Соціально-економічний розвиток України: проблеми та перспективи : колективна монографія / ред. О.В. Манойленко. Харків : НТУ «ХПІ», 2015. Розд. 5. С. 229-242.

10. Раєвнєва О.В., Аксьонова І.В., Свидло Г.І. Статистичні методи оцінки регіонального розвитку. Харків, 2016.328 с.

11. Дакус А.В., Сімченко Н.О. Економічний розвиток підприємства: сутність та визначення. Актуальні проблеми економіки та управління : збірник наукових праць молодих вчених. 2012. URL: https://ela.kpi.ua/handle/123456789/12350 (дата звернення: 12.05.2020).

12. Кифяк В.Ф. Теоретичні основи визначення категорії «розвиток підприємства». Економічний аналіз. 2011. Вип. 8. Ч. 2. С. $190-194$.

13. Кузьмін О.С., Дідик А.М. Ознаки та особливості полівекторного розвитку підприємств. Вісник Національного університету «Львівська політехніка». Менеджмент та підприємництво в Украӥні: етапи становлення і проблеми розвитку. 2015. № 819 . C. $3-8$.

14. Нечепуренко М.Н. Проблеми економічного розвитку підприємств. Питання економічних наук. 2006. № 1 (17). С. $23-25$.

15. Штулер І.Ю. Еволюція теорій економічного розвитку у сучасному вимірі знань. Глобальні та національні проблеми економіки. 2016. Вип. 9. С. 216-219.

16. Горіна Г.О. Діалектика поняття «розвиток підприємства». Причорноморські економічні студії. 2016. Вип. 8. С. $123-127$.

17. Погорєлов Ю.С. Розвиток підприємства: поняття та види. Культура народов Причерноморья. 2006. № 88. С. 75-81.

\section{References:}

1. Ramsey F. (1928) Mathematical Theory of saving. Economic Journal. Vol. 38. P. 543-559.

2. Rikardo D. (1955) Sochineniya v pyati tomah. M.: Gospolitizdat. T. 1 : "Nachalo ekonomii i nalogovogooblozheniya" [The beginning of economy and taxation]. $360 \mathrm{~s}$

3. Marks K. (1960) Kapital. T. 1. M., 907 s.

4. Smit A. (1993) Issledovanie o prirode i prichinah bogatstva narodov. [Research on the nature and causes of the wealth of peoples]. M. : Nauka. Kn. I-III. 148 s.

5. Ekonomichniy entsiklopedichniy slovnik : u 2 t. T. 1 / za red. S.V. Mochernogo. Lviv : SvIt, 2005. 616 s.

6. Konenkov R.A. (1988) Diagnostika kachestva ekonomicheskogo rosta i razvitiya predpriyatiya. [Diagnostics of the quality of economic growth and enterprise development] Volgograd : Volgogradskaya pravda, $112 \mathrm{~s}$

7. Nadtoka T.B., KakunIna G.A. (2011) Sotsialniy rozvitok promislovogo pidpriemstva ta mehanIzmi yogo upravlinnya. [Social development of an industrial enterprise and mechanisms of its management]. Upravlencheskie tehnologii $\mathrm{v}$ reshenii sovremennyih problem razvitiya sotsialno-ekonomicheskih sistem : monografiya / za zag. red. O.V. Martyakovoyi. Donetsk : DVNZ "DonNTU". S. 564-569.

8. Plugina Yu.A. (2013) Rozvitok personalu pIdpriemstva: pidhodi, sutnist, modeli. [Enterprise staff development: approaches, essence, models]. Visnik ekonomiki transportu i promislovosti. Vip. 42. S. 323-327.

9. Poberezhniy R.O., Poberezhna N.M. (2015) Metodologichni aspekti suchasnih pidhodiv do sutnosti rozvitku pIdpriemstva $\mathrm{v}$ umovah minlivogo zovnIshnogo seredovischa. [Methodological aspects of modern approaches to the essence of enterprise development in a changing environment] Sotsialno-ekonomichniy rozvitok Ukrayini: problemi ta perspektivi : kol. monografiya / red. O.V. Manoylenko. Harkiv : NTU "HPI”. Rozd. 5. S. 229-242.

10. Raevneva O.V., Aksonova I.V., Svidlo G.I. (2016) Statistichni metodi otsinki regionalnogo rozvitku. [Statistical methods for assessing regional development]. HarkIv, $328 \mathrm{~s}$.

11. Dakus A.V., Simchenko N.O.(2012) Ekonomichniy rozvitok pidpriemstva: sutnist ta viznachennya. [Economic development of the enterprise: essence and definition] Aktualni problemi ekonomiki ta upravlinnya : zbirnik naukovih prats molodih vchenih. URL: https://ela.kpi.ua/handle/123456789/12350 (accessed 12 May 2020).

12. Kifyak V.F. (2011) Teoretichni osnovi viznachennya kategoriyi "rozvitok pidpriemstva". [Theoretical bases of definition of a category "enterprise development"]. Ekonomichniy analiz. Vip. 8. Ch. 2. S. 190-194.

13. Kuzmin O.E., Didik A.M. (2015) Oznaki ta osoblivosti polivektornogo rozvitku pidpriemstv. [Signs and features of polyvector development of enterprises]. Visnik Natsionalnogo universitetu "Lvivska politehnika". Menedzhment ta pidpriemnitstvo v Ukrayini: etapi stanovlennya i problemi rozvitku. № 819. S. 3-8.

14. Nechepurenko M.N. (2006) Problemi ekonomichnogo rozvitku pidpriemstv [Problems of economic development of enterprises] / Pitannya ekonomichnih nauk. № 1 (17). S. 23-25.

15. Shtuler I.Yu. (2016) Evolyutsiya teoriy ekonomichnogo rozvitku u suchasnomu vimiri znan. [Evolution of theories of economic development in the modern dimension of knowledge]. Globalni ta natsionalni problemi ekonomiki. Vip. 9. S. $216-219$.

16. Gorina G.O. (2016) DIalektika ponyattya "rozvitok pidpriemstva" [Dialectics of the concept of "enterprise development"] Prichornomorski ekonomichni studiyi. Vip. 8. S. 123-127.

17. Pogorelov Yu.S. Rozvitok pidpriemstva: ponyattya ta vidi [Enterprise development: concepts and types] / Kultura narodov Prichernomorya. 2006. № 88. S. 75-81. 
Klimenko Lidiya, Zagorodniuk Oksana, Halahur Yuliya Uman National University of Horticulture

\section{DIALECTICS OF THE CONCEPT OF "ECONOMIC DEVELOPMENT OF ENTERPRISES” IN THE MANAGEMENT SYSTEM}

Modern processes of globalization and influence of the transformation economic system require the new going near consideration of basic principles of development of national economy and development of effective directions of economic development of enterprises of Ukraine. The aim of the article is generalization of category "economic development of enterprise" and ground of control system by the enterprises at the modern terms of structural transformations. The methodological bases of scientific research are scientific and special methods of scientific knowledge (methods of scientific deduction and induction, comparison and systematization, synthesis). The study of world economic thought and the generalization of modern scientific dialectical justifications of the concept of "economic development of the enterprise", contributed to the formation of the author's vision of this definition. It is determined that economic development is, first of all, irreversible, controlled, purposeful, natural quantitative-qualitative and essential changes of the economic system of the economic entity, which are caused by the influence of economic contradictions, needs and interests, based on the laws of dialectics. Studies of the diversity of economic growth and structural changes in the system of economic development of the national economy are reflected in the interdependence of structural components of economic development of enterprises. Content analysis of the formed definitions and systematization of the scale of modern structural changes in the economy of Ukraine, contributed to the formation of the classification of types of development of economic entities on the basis of semantic criteria. The diversity of scientific research and the scale of this issue require the introduction of modern methods of management decisions aimed at specifying priorities, increasing resource provision and developing effective development strategies are established. The organizational and economic levers of balanced stable development of domestic enterprises are the involvement of competitive high-tech innovative production processes under the conditions of integration efforts of organizations and enterprises of the external and internal environment is proved in this article.

Key words: economic development, management, administrative management, development strategies, competitiveness.

JEL classification: O10, F01, M11 